\title{
正中縦割式と片開き式椎弓形成術の比較
}

\author{
那覇市立病院整形外科 \\ 米嵩理・屋良哲也 \\ 仲宗根 朝 洋 · 三 好 晋 爾 \\ ハートライフ病院整形外科 \\ 仲 村一 郎・松 元 悟 \\ 琉球大学整形外科 \\ 六角高 祥・金 谷 文 則

\section{Comparison of Spinous Process-Splitting Laminoplasty and En-Bloc Open Door Laminoplasty} \\ Tadashi Yonetake, Tetsuya Yara, Tomohiro Nakasone, \\ and Shinji Miyoshi \\ Department of Orthopaedic Surgery, \\ Naha City Hospital, Okinawa, Japan \\ Ichiro Nakamura, and Satoru Matsumoto \\ Department of Orthopaedic Surgery, \\ Heart Life Hospital, Okinawa, Japan \\ Takayoshi Rokkaku, and Fuminori Kanaya \\ Department of Orthopaedic Surgery, School of Medicine, \\ University of Ryukyus, Okinawa, Japan
}

We investigated and compared surgical outcomes and postoperative complications in 106 patients who underwent spinous process-splitting laminoplasty and en-bloc open door laminoplasty. Seventy-nine patients were male and 27 were female. Their age ranged from 32 to 84 years. Fifty-eight patients underwent spinous process-splitting laminoplasty [cervical spondylotic myelopathy (CSM) in 41 patients, ossifiction of posterior longitudinal ligament (OPLL) in 9, and cervical hernia in 8] and 48 patients underwent enbloc open door laminoplasty (CSM in 36 patients, OPLL in 7, and cervical hernia in 5). Preoperative and postoperative JOA (Japanese Orthopaedic Association) scores, improvement ratio in JOA scores, surgery time, amount of hemorrhage, and postoperative complications were investigated.

For patients who underwent spinous process-splitting laminoplasty and en-bloc open door laminoplasty, the average preoperative JOA score was 10 and 11 points, the average postoperative JOA score was 14 and 14 points, and improvement ratio was 50 and $52 \%$, respectively. The average surgery time and average hemorrhage did not differ signifficantly between groups.

However, the incidence of liquorrhea tended to be higher in the spinous processsplitting laminoplasty group.

Key words : spinous process-splitting laminoplasty（正中縦割式椎弓形成術）, en-bloc open door laminoplasty（片開き式椎弓形成術）, liquorrhea（髄液漏） 


\section{は じ めに}

䅡部脊髄症に対して行われる脊柱管拡大術は, 前方 除圧固定術と比較して臨床成績に差を認めないと報告 されている2．また，正中縦割式椎弓形成術（正中縦 割式），片開き式椎弓形成術（片開き式）のそれぞれ について良好な成績が報告されているが324)，両者を比 較した報告は少ない ${ }^{155}$.

今回われわれは正中縦割式と片開き式の手術成績, 術後合併症について比較, 検討を行った.

\section{対象および方法}

1996 年から 2003 年の間に当院およびハートライフ 病院で施行した椎弓形成術 106 例を対象とした。男性 79 例，女性 27 例，手術時年齢は $32 \sim 84$ 歳（平均 60 歳) で経過観察期間 2 力月 6 年 4 力月（平均 1 年 4 カ月）であった.

主な術式として, 1996 年から 1998 年は正中縦割式 を, 1999 年から 2003 年は片開き式を選択した.

疾患の内訳は頚椎症性春髄症 (CSM) 77 例, 後縦 勒带骨化症（OPLL）16 例，椎間板ヘルニア 13 例で あった．正中縦割式は 58 例（CSM 41 例，OPLL 9 例，ヘルニア 8 例）であり，片開き式は 48 例（CSM 36 例, OPLL 7 例，ヘルニア 5 例) であった.

正中縦割式は Threadwire saw（T-saw）を椎弓下 に通して棘突起を正中で縦割した後, 両側の椎弓を椎 間関節内縁でエアトームを用いて削り，両側をヒンジ として椎弓を開いて，AW ガラスセラミックあるい はハイドロキシアパタイト（HA）椎弓スペーサーを 縦割した棘突起間に縫着固定した。片開き式は正中縦 割式と同様に両側の椎弓を椎間関節内縁で削り, 片側 をヒンジ側, 片側を切離側とし, 切離側を持ち上げ, HA 椎弓スペーサーを縫着固定した。拡大範囲（正中 縦割式：片開き式）はC 3 から C7 が 99 例 (51:48), C3から T1 が 3 例（3：0)，C2 から C5 が 1 例（1:0), C2 から C7 が 3 例（3：0）であった。

両術式の術前, 術後の日整会頚䯣症治療成績判定基 準 (JOA スコア)，平林法によるスコア改善率，手術 時間, 術中出血量, 術後合併症について比較, 検討を 行った.
結

果

JOA スコアは正中縦割式が術前 $4 \sim 14$ (平均 $\pm S D$; $10 \pm 2.31 ）$ 点が術後 $7 \sim 17(14 \pm 2.20)$ 点, 片開き式 は術前 $0 \sim 15 （ 11 \pm 2.79 ）$ 点が術後 $8 \sim 17 \quad(14 \pm 2.24)$ 点と, 両術式とも術後は有意に改善した.

スコア改善率は正中縦割式が 0 ～100 (50 28.0$)$ \%，片開き式が 0 １00（52 $29.0 ％$ \%であり，両術 式間で有意差を認めなかった。

疾患別のスコア改善率は CSM では正中縦割式（41 例）が平均 $51 \%$, 片開き式 (36 例) が平均 $49 \%$ であっ た。 OPLL では正中縦割式（9例）が平均 $49 \%$, 片 開き式（7 例）が平均 $58 \%$ であり，椎間板ヘルニア では正中縦割式（8例）が平均 $46 \%$, 片開き式 (5 例) が平均 $78 \%$ であった．各疾患とも両術式間で有意差 を認めなかった.

手術時間は正中縦割式が 90〜385 分 (平均 162 分), 片開き式が 99〜305 分（平均 158 分）であり, 有意差 はなかった。

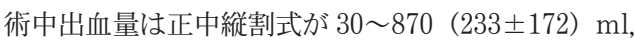
片開き式が 30１050（199 210） で有意差はなかっ た.

術後合併症は髄液漏が 11 例（正中縦割式 9 例，片 開き式 2 例）に認められた。 スペーサーの転位が 3 例 にみられ，すべて正中縦割式で AW ガラスセラミッ ク椎弓スペーサーを使用した例であった.

髄液漏の原因について調べると, 不明が 8 例（正中 縦割式 6 例, 片開き式 2 例）で, 原因のわかっている

表 1 髄液漏を認めた症例

\begin{tabular}{ccccc}
\hline \hline 症例 & 術式 & 疾患 & 原因 & \multicolumn{2}{c}{ 䯣液ドレナージ } \\
\hline 1 & 正中縦割 & CSM & 不明 & $(-)$ \\
2 & 正中縦割 & CSM & 不明 & $(+)$ \\
3 & 正中縦割 & CSM & 不明 & $(+)$ \\
4 & 正中縦割 & CSM & 不明 & $(+)$ \\
5 & 正中縦割 & CSM & 不明 & $(+)$ \\
6 & 正中縦割 & CDH & 不明 & $(+)$ \\
7 & 正中縦割 & CSM & エアドリル & $(-)$ \\
8 & 正中縦割 & CDH & 電気メス & $(-)$ \\
9 & 正中縦割 & OPLL & 電気メス & $(+)$ \\
10 & 片開き & CSM & 不明 & $(-)$ \\
11 & 片開き & OPLL & 不明 & $(+)$ \\
\hline
\end{tabular}


ものはエアドリルによる硬膜損傷が 1 例，電気メスに よる硬膜損傷が 2 例であった（表 1 )。さらに正中縦 割式を施行し, 原因不明の䯣液漏を認めた 6 例の正中 縦割の分割回数について調べると, 施術椎弓を 1 回で いっきに縦割した 35 例中 4 例, 2 回に分割した 15 例 中 2 例に䯣液漏を認めた. 3 回以上に分割した 8 例に は髄液漏は認めなかった。

\section{症}

例

症例 160 歳，男性．主訴は歩行障害であった。単 純機能撮影にて C3 後方すべりを認め, MRIにて C3/4 に高度の脊柱管狭窄を認めた。C2 から C5 の正
中縦割式に加えて，C3/4 に外側塊プレートを用いた 後方椎間固定を併用した。JOA スコアは術前 9 点が 術後 11 点と改善し，スコア改善率は $25 \%$ であった (図 1).

症例 236 歳, 女性. 主訴は歩行障害および左上肢 痛であった。 MRI 上 C4/5，5/6，6/7 の 3 椎間にへ ルニアを認め, C5/6 ではへルニアが春柱管内左外側 に偏位していた。左側を切離側とする片開き式に加え て C5/6ヘルニアの摘出を行った。JOA スコアは術 前 10 点が術後 17 点へと改善し, 改善率は $100 \%$ であっ た（図 2).
術前

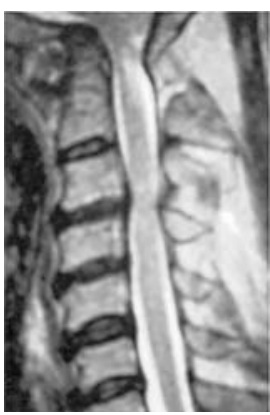

図 160 歳 男性 CSM

術前単純機能撮影で C $3 / 4$ の不安定性を認める.

術後 C2-5 の正中縦割式に加え, C $3 / 4$ の後方椎間固定術を施行した.

術後
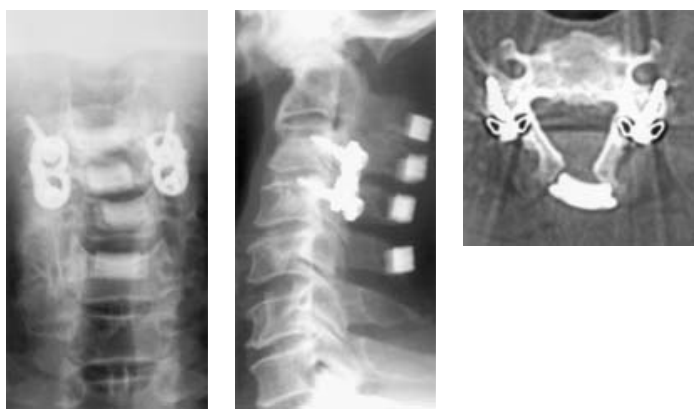

術後

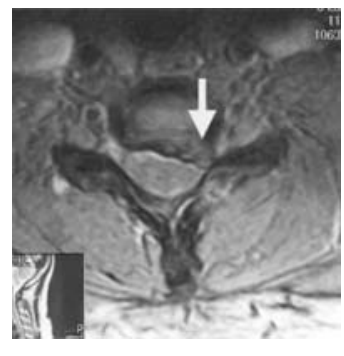

C $5 / 6$

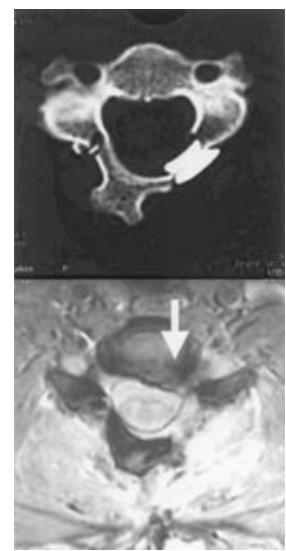

図2 36 歳 女性 $\mathrm{CDH}$

術前 C5 $/ 6$ で春柱管内左外側に突出するへルニアを認める。

術後 C3-7 の片開き式に加え，ヘルニア摘出術を施行した。 
考察

頝椎椎弓形成術は正中縦割式（黒川法）と片開き式 (平林法) が広く行われており, 林ら ${ }^{1)}$, Yue ら ${ }^{5)}$ は両 術式を比較し, 手術成績に有意差はなかったと報告し ており，われわれの結果と同様であった．術中出血量 については一般に片開き式では硬膜外静脈叢損傷に伴 い出血量が増加するという報告もあるが，われわれの 症例においては両術式に有意差は認めなかつた.

両術式の特徴として, 正中縦割式では両側がヒンジ 側となり，左右対称に骨移植が可能であり，大量の移 植骨を置くことができるため, 後方固定術を併用する 際に有利であることが利点として挙げられるが，髄液 漏が多い傾向を認めた。片開き式では外側に偏位した ヘルニアに対して，ヘルニア摘出を併用できることが 利点であった.

正中縦割式に髄液漏が多く発生した原因として, 正 中縦割を 3 回以上に分けて行った群に髄液漏を認めな かったことから，狭窄の強い椎弓下へ T-saw を 1 度 に数椎間に通す操作や数椎間の棘突起をまとめて縦割 する際の摩擦で硬膜を損傷したのではないかと考えら れた。 また後弯頝椎に対しては, 前述した操作がさら に困難で髄液漏を起こしやすい可能性が考えられる. 本症例では正中縦割式を行い, 髄液漏を認めた 9 例中
3 例と髄液漏を認めなかつた 49 例中 6 例が後弯頚椎 であり, 髄液漏の発生率では両群に有意差を認めなかっ た. 一方, 術中の頚椎アライメントは通常と変化して いる可能性があり, 今後の検討が必要である.

$$
\text { ま と め }
$$

(1)正中縦割式, 片開き式における手術成績, 術後合 併症について比較, 検討を行つた.

(2)スコア改善率, 手術時間, 術中出血量では, 両術 式に有意差はなかった。

(3)正中縦割式に髄液漏が多い傾向を認めた.

\section{参 考 文 献}

1）林 協司ら：頸椎症性脊髄症に対する椎弓形成術後の 頸椎アライメント一片開き式と棘突起縦割式の比較一. 整外と災外, $51: 312-314,2002$.

2）岩崎幹季ら：頚椎椎間板ヘルニアによる䅡部脊䯣症に 対する脊柱管拡大術の治療成績一前方固定術との比較検 討一. 別冊整形外科, $29: 125-131,1996$.

3）黑川高秀, 中村耕三, 星野雄一：その後の棘突起縦割 式脊柱管拡大術. 臨整外, $30: 566-571,1995$.

4）竹内則博ら：片開き式頚部脊柱管拡大術の長期成績 (術後 7 年以上). 別冊整形外科, $29: 138-142,1996$.

5) Yue, W. M. et al.: Results of cervical laminoplasty and a comparison between single and double trapdoor techniques. J. Spinal Disord., $13:$ 329-335, 2000. 